\title{
MAQASHID SYARI'AH DALAM PEMBAHARUAN HUKUM EKONOMI ISLAM
}

\author{
Samud \\ Fakultas Syariah dan Ekonomi Islam \\ Institut Agama Islam Negeri Syekh Nurjati Cirebon \\ J1. Perjuangan By Pass Sunyaragi Cirebon \\ Email: samud_iaincrb@ymail.com
}

\begin{abstract}
Abstrak
Pembaruan hukum Islam merupakan suatu keniscayaan, terutama di era yang sangat cepat perubahannya ini sebagai akibat kemajuan di bidang industri, perdagangan, jasa, kontrak perjanjian, teknologi, komunikasi, dan lain-lain. Maqashid syariah adalah untuk melestarikan tatanan dunia dengan jaminan hak-hak asasi manusia sebagai subjek dalam pelestarian dan pemakmuran alam. Perspektif ini berusaha untuk memelihara hak-hak manusia yang terarah pada diekspresikannya amal dan status sosial individu di tengahtengah masyarakat. Ekonomi syariah harus dilaksanakan dengan memelihara nilai keadilan dan menghindari unsur-unsur kezaliman. Segala bentuk aktifitas ekonomi yang mengandung unsur penindasan tidaklah dibenarkan. Setiap aktifitas ekonomi harus memperhatikan keseimbangan antara pihak-pihak yang melakukan transaksi. Prinsip ini menekankan perlu adanya keseimbangan sikap dalam melakukan aktifitas perekonomian.
\end{abstract}

Kata Kunci: Maqashid Syari'ah, Pembaharuan Hukum, dan Ekonomi Islam

\begin{abstract}
The reform of Islamic law is a necessity, especially in this era of rapid change as a result of progress in industry, trade, services, contractual agreements, technology, communications, and others. Maqashid shariah is to preserve the world order with the guarantee of human rights as a subject in the preservation and prosperity of nature. This perspective seeks to preserve the human rights that are directed towards the expression of charity and the social status of individuals in the midst of society. Sharia economy must be implemented by maintaining the value of justice and avoiding the elements of injustice. Any form of economic activity that contains elements of oppression is not justified. Every economic activity should pay close attention to the balance between the parties who make the transaction. This principle emphasizes the need for a balance of attitude in conducting economic activities.
\end{abstract}

Keywords: Maqashid Syari'ah, Legal Reform, and Islamic Economics 


\section{A. Pendahuluan}

Penerapan syari'ah dalam ekonomi syari'ah setidaknya dipahami dalam dimensi eksklusif dan inklusif. ${ }^{1}$ Secara ekslusif, artinya menempatkan syari'ah dalam posisi internal dan integratif dari ajaran Islam sebagai sebuah kesatuan yang sistematis, menyeluruh (kaffah), dan mandiri. Secara internal, semua pemeluk Islam (muslim) mutlak menempatkan syari'ah di atas segala-galanya yang harus pula terimplementasi dalam segala dimensi kehidupan, tak terkecuali di bidang ekonomi. Dalam hal ini, sistem ekonomi syari'ah merupakan pilihan yang tidak mungkin ditawar-tawar lagi. Dengan tidak menempatkan syari'ah dalam setiap dimensi kehidupannya, akan berakibat fatal karena telah melakukan pengingkaran terhadap pesan al-Qur'an untuk ber-Islam secara kaffah (udkhulv fi-as-silmi kaffah).

Maqashid syariah adalah jantung dalam ilmu ushul fiqih, karena itu maqashid syariah menduduki posisi yang sangat penting dalam merumuskan ekonomi syariah, Maqashid syariah tidak saja diperlukan untuk merumuskan kebijakankebijakan ekonomi makro (moneter, fiscal; public finance), tetapi juga untuk menciptakan produk-produk perbankan dan keuangan syariah serta teori-teori ekonomi mikro lainnya. Maqashid syariah juga sangat diperlukan dalam membuat regulasi perbankan dan lembaga keuangan syariah. ${ }^{2}$

Para ulama ushul fiqih sepakat bahwa pengetahuan maqashid syariah menjadi syarat utama dalam berijtihad untuk menjawab berbagai problematika kehidupan ekonomi dan keuangan yang terus berkembang. Maqashid syariah tidak saja diperlukan untuk merumuskan kebijakan-kebijakan ekonomi makro

1 M. Arifin Hamid, Hukum Ekonomi Islam (Ekonomi Syariah) Di Indonesia Aplikasi dan Prospektifnya, (Bogor: Ghalia Indonesia, 2007), 22

2 Agustianto Minka, Maqashid Syariah Dalam Ekonomi Dan Keuangan Syariah, ( Jakarta:t.p, 2013), 172 (moneter, fiscal; public finance), tetapi juga untuk menciptakan produk-produk perbankan dan keuangan syariah serta teoriteori ekonomi mikro lainnya. Maqashid syariah juga sangat diperlukan dalam membuat regulasi perbankan dan lembaga keuangan syariah. ${ }^{3}$

Perkembangan tersebut diharapkan semakin melebar meliputi aspek dan cakupan yang sangat luas, seperti kebijakan ekonomi negara, ekonomi pemerintah daerah, ekonomi makro (kebijakan fiskal, public finance, strategi mengatasi kemiskinan serta pengangguran, inflasi, kebijakan moneter), dan permasalahan ekonomi lainnya, seperti upah dan perburuhan dan sebagainya. Dalam perkembangan di bidang lembaga perekonomian agar mampu bersaing dan sesuai dengan kebutuhan masyarakat bisnis modern, diperlukan inovasi-inovasi produk dengan tetap mematuhi prinsip-prinsip syariah dalam operasionalnya. ${ }^{4}$

Perkembangan tersebut juga berimplikasi kepada banyaknya masyarakat Indonesia yang beraktivitas dalam ekonomi Islam, maka sangat dimungkinkan terjadinya sengketa hukum di bidang ekonomi Islam. Oleh karena itu, dibutuhkan aplikasi hukum Islam dalam praktik ekonomi Islam di Indonesia. Praktik ekonomi Islam di bidang lembaga perekonomian mengalami akselerasi yang signifikan, baik di dunia maupun di Indonesia.

\section{B. Maqashid Syari'ah}

\section{Pengertian Maqashid Syariah}

Maqashid syari'ah terdiri dari dua kata, maqâshid dan syarî'ah. Kata maqâshid merupakan bentuk jama' dari maqshad yang berarti maksud dan tujuan, sedangkan syari'ah mempunyai pengertian hukumhukum Allah yang ditetapkan untuk

\footnotetext{
3 Amir syaifuddin, Ushul FiQh 2, (jakarta: Prenadamedia Group, 2008), 231

${ }^{4}$ Suhrawardi K. Lubis, Hukum Ekonomi Islam, (Jakarta: Sinar Grafika, 2000), 1
} 
manusia agar dipedomani untuk mencapai kebahagiaan hidup di dunia maupun di akhirat. Maka dengan demikian, maqâshid syarîah berarti kandungan nilai yang menjadi tujuan pensyariatan hukum. Maka dengan demikian, maqâshid syarîah adalah tujuan-tujuan yang hendak dicapai dari suatu penetapan hukum. ${ }^{5}$ Izzuddin ibn Abd as-Salâm, sebagaimana dikutip oleh Khairul Umam, mengatakan bahwa segala taklif hukum selalu bertujuan untuk kemaslahatan hamba (manusia) dalam kehidupan dunia dan akhirat. ${ }^{6}$

Secara bahasa maqâshid syarîah terdiri dari dua kata yaitu maqâshid dan Syarîah. Maqâshid berarti kesengajaan atau tujuan, maqâshid merupakan bentuk jama dari maqsud yang berasal dari suku kata qashada yang berarti menghendaki atau memaksudkan, maqâshid berarti hal-hal yang dikehendaki dan dimaksudkan. ${ }^{7}$ berarti:

Sedangkan syari'ah secara bahasa yang

Jalan menuju sumber air, jalan mепијu sumber air dapat juga diartikan berjalan menuju sumber kehidupan. ${ }^{8}$

Para ulama mutaakhirin (kontemporer) mendefinisikan maqâshid syariah sebagai berikut:

a. Menurut Thahir Ibnu Ashur, maqâshid syarîah adalah maknamakna dan hikmah-hikmah yang telah dijaga oleh Allah dalam segala ketentuan hukum syariah baik yang kecil maupun yang besar dan tidak ada pengkhususan dalam jenis tertentu dari hukum syariah. ${ }^{9}$

5 Asafri Jaya, Konsep Maqâshid Syarîah Menurut ash-Shâtibi, (Jakarta: Raja Grafîndo Persada, 1996), 5.

6 Khairul Umam, Ushûl Fîqih, (Bandung, Pustaka Setia, 2001), 125

7 Ibnu Mansur al-Afriqi, Lisan al-Arab, (Beirut: Dâr al-Sadr, t.th), Juz 8, 175

${ }^{8}$ Fazlur Rahman, Islam, alih bahasa: Ahsin Muhammad, (Bandung: Pustaka, 1994), 140.

${ }^{9}$ Ahmad ar-Raisuni, Nazhâriyyat al-Maqâshid "inda al-Imâm ash-Shâtibi, (Beirut: al-Maahad alAlami li al-Fikr al-Islâmi, 1992), 13 b. Allah al-Fasy mendefinisikan maqâshid syarîah sebagai tujuantujuan dan rahasia-rahasia yang telah ditetapkan Allah dalam setiap hukum. ${ }^{10}$

c. Ahmad Raysuni mendefinisikan maqâshid syarîah sebagai tujuantujuan yang telah ditetapkan oleh Allah untuk merealisasikan kemaslahatan hamba. ${ }^{11}$

d. Muhammad al-Yubi mendefinisikan maqâshid syarîah adalah makna-makna dan hikmah-hikmah yang telah ditetapkan oleh Allah dalam syariatnya baik yang khusus atau umum yang bertujuan untuk merealisasikan kemaslahatan hamba. ${ }^{12}$

Allah tidak membutuhkan ibadah seseorang, karena ketaatan dan maksiat hamba tidak memberikan pengaruh apa-apa terhadap kemulian Allah. Jadi, sasaran manfaat hukum tidak lain adalah kepentingan manusia. Maqâshid syarî'ah mengandung pengertian umum dan pengertian khusus. Pengertian yang bersifat umum mengacu pada apa yang dimaksud oleh ayat-ayat hukum atau hadits-hadits hukum, baik yang ditunjukkan oleh pengertian kebahasaannya atau tujuan yang terkandung di dalamnya. Pengertian yang bersifat umum itu identik dengan pengertian istilah maqâshid as-syari' (maksud Allah dalam menurunkan ayat hukum, atau maksud Rasulullah dalam mengeluarkan hadits hukum). Sedangkan pengertian yang bersifat khusus adalah substansi atau tujuan yang hendak dicapai oleh suatu rumusan hukum.

10 Allal Al-Fasy, Maqâshid asy-Syarî'ah alIslâmiyyah wa Makârimuha, (KSA: Dârul Garb AlIslamy. 1993), (Cet.5), 36

${ }_{11}$ Ahmad ar-Raisuni, Nazhâriyyat al-Maqâshid ..., 13

${ }^{12}$ Muhammad Sa ${ }^{e e}$ ad al-Yubi, Maqâshid asySyarî'ah al-Islâmiyah wa Alaqâtuha bi al-Adillah asy-Syar' îyyah (KSA: Dâr al-Hijrah li an-Nasyr wa at-Tauzi, 1998), Cet.1, 35 
Sementara itu Wahbah az-Zuhaili mendefinisikan maqâshid syarî'ah dengan makna-makna dan tujuan-tujuan yang dipelihara oleh syara' dalam seluruh hukumnya atau sebagian besar hukumnya, atau tujuan akhir dari syari'at dan rahasiarahasia yang diletakkan oleh syara' pada setiap hukumnya. ${ }^{13}$ Kajian teori maqâshid syarî ${ }^{e e}$ dalam hukum Islam adalah sangat penting. Urgensi itu didasarkan pada pertimbangan-pertimbangan sebagai berikut. Pertama, hukum Islam adalah hukum yang bersumber dari wahyu Tuhan dan diperuntukkan bagi umat manusia. Oleh karena itu, ia akan selalu berhadapan dengan perubahan sosial. Dalam posisi seperti itu, apakah hukum Islam yang sumber utamanya (Alquran dan Sunnah) turun pada beberapa abad yang lampau dapat beradaptasi dengan perubahan sosial.

Jawaban terhadap pertanyaan itu baru bisa diberikan setelah diadakan kajian terhadap berbagai elemen hukum Islam, dan salah satu elemen yang terpenting adalah teori maqâshid syarî́ ${ }^{e} a h$. Kedua, dilihat dari aspek historis, sesungguhnya perhatian terhadap teori ini telah dilakukan oleh Rasulullah SAW., para sahabat, dan generasi mujtahid sesudahnya. Ketiga, pengetahuan tentang maqâshid syarîah merupakan kunci keberhasilan mujtahid dalam ijtihadnya, karena di atas landasan tujuan hukum itulah dikembalikan. Abdul Wahhab Khallaf, seorang pakar ushûl fiqh, menyatakan bahwa nash-nash syarî ${ }^{\text {ee }}$ ah itu tidak dapat dipahami secara benar kecuali oleh seseorang yang mengetahui maqâshid syarîah (tujuan hukum). ${ }^{14}$

Pendapat ini sejalan dengan pandangan pakar fiqh lainnya, Wahbah az-Zuhaili, yang mengatakan bahwa pengetahuan tentang maqâshid syariah merupakan persoalan dharûri (urgen) bagi mujtahid ketika akan memahami nash dan membuat

${ }^{13}$ Wahbah az-Zuhaili, Ushûl al-Fiqh al-Islâmi, (Beirut: Dâr al-Fikr, 1986), 1017

${ }^{14}$ Abd al-Wahab Khallaf, Ilmu Ushûl al-Fiqh, (Kairo: Maktabah al-Da'wah al-Islâmiyah, 1968), 198. istinbath hukum, dan bagi orang lain dalam rangka mengetahui rahasia-rahasia syarîah. ${ }^{15}$ Memang, bila diteliti semua perintah dan larangan Allah dalam Alquran, begitu pula suruhan dan larangan Nabi SAW., dalam sunnah yang terumuskan dalam fiqh, akan terlihat bahwa semuanya mempunyai tujuan tertentu dan tidak ada yang sia-sia. Semuanya mempunyai hikmah yang mendalam, yaitu sebagai rahmat bagi umat manusia, sebagaimana yang ditegaskan dalam beberapa ayat al-Quran, di antaranya dalam surah al-Anbiya': 107, tentang tujuan Nabi Muhammad diutus:

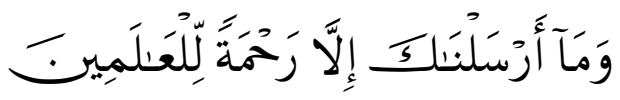

Artinya: "Dan tidaklah Kami mengutusmu, kecuali menjadi rahmat bagi seluruh alam" (QS. Al-Anbiya':107)

Rahmat untuk seluruh alam dalam ayat di atas diartikan dengan kemaslahatan umat. Sedangkan, secara sederhana maslahah itu dapat diartikan sebagai sesuatu yang baik dan dapat diterima oleh akal yang sehat. Diterima akal mengandung pengertian bahwa akal itu dapat mengetahui dan memahami motif di balik penetapan suatu hukum, yaitu karena mengandung kemaslahatan untuk manusia, baik dijelaskan sendiri alasannya oleh Allah atau dengan jalan rasionalisasi. Suruhan Allah SWT., untuk berzikir dan shalat dijelaskan sendiri oleh Allah, sebagaimana yang termaktub dalam ayat berikut:

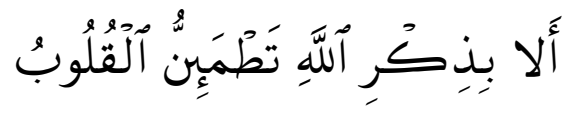

Artinya: "Ketahuilah bahwa dengan berzikir itu hati akan tenteram". (Q.S. AlRa'd: 28)

15 Wahbah az-Zuhaili, Ushûl al-Fiqh alIslâmi..., 1017 


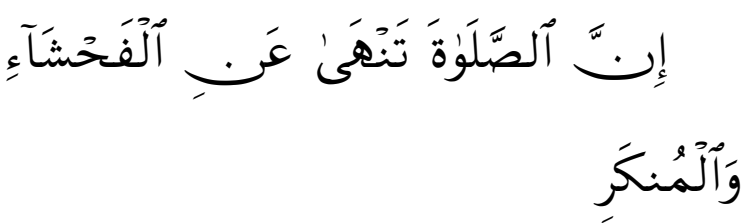

Artinya: "Sesungguhnya shalat itu mencegah dari perbuatan keji dan munkar". (Q.S Al-'Ankabut: 45)

Memang ada beberapa aturan hukum yang tidak dijelaskan secara langsung oleh syari' (pembuat syari'at) dan akalpun sulit untuk membuat rasionalisasinya, seperti penetapan waktu shalat zhuhur yang dimulai setelah tergelincirnya matahari. Meskipun begitu tidaklah berarti penetapan hukum tersebut tanpa tujuan, hanya saja barangkali rasionalisasinya belum dapat dijangkau oleh akal manusia.

Kandungan maqâshid syarîah dapat diketahui dengan merujuk ungkapan ashShātibi, seorang tokoh pembaru ushûl fiqh yang hidup pada abad ke-8 Hijriah, dalam kitabnya al-Muwâfaqât fi ushûl asySyarîah. Di situ beliau mengatakan bahwa sesungguhnya syari'at itu ditetapkan tidak lain untuk kemaslahatan manusia di dunia dan di akhirat. ${ }^{16}$

Jadi, pada dasarnya syari'at itu dibuat untuk mewujudkan kebahagiaan individu dan jama'ah, memelihara aturan serta menyemarakkan dunia dengan segenap sarana yang akan menyampaikannya kepada jenjang-jenjang kesempurnaan, kebaikan, budaya, dan peradaban yang mulia, karena dakwah Islam merupakan rahmat bagi semua manusia.

Dari pengertian di atas, dapat dikatakan bahwa yang menjadi bahasan utama dalam maqâshid syarî̀ ah adalah hikmah dan illat ditetapkan suatu hukum. Dalam kajian ushûl fiqh, hikmah berbeda dengan illat. Illat adalah sifat tertentu yang jelas dan dapat diketahui secara objektif (zahîr), dan ada tolak ukurnya (mundhabit), dan sesuai dengan ketentuan hukum (munâsib) yang keberadaannya merupakan penentu adanya

16 Ash-Shâtibi, Al-Muwâfaqât fî Ushûl asySyarî'ah, (Riyadh: Maktabah al-Riyadh al-Haditsah, tth), 6 hukum. Sedangkan hikmah adalah sesuatu yang menjadi tujuan atau maksud disyariatkannya hukum dalam wujud kemaslahatan bagi manusia.

Maslahat secara umum dapat dicapai melalui dua cara:

a. Mewujudkan manfaat, kebaikan dan kesenangan untuk manusia yang disebut dengan istilah jalb al-manafi'. Manfaat ini bisa dirasakan secara langsung saat itu juga atau tidak langsung pada waktu yang akan datang.

b. Menghindari atau mencegah kerusakan dan keburukan yang sering diistilahkan dengan dar' al-mafâsid. Adapun yang dijadikan tolok ukur untuk menentukan baik buruknya (manfaat dan mafsadahnya) sesuatu yang dilakukan adalah apa yang menjadi kebutuhan dasar bagi kehidupan manusia. Tuntutan kebutuhan bagi kehidupan manusia itu bertingkat-tingkat, yakni kebutuhan primer, sekunder, dan tersier.

Menurut telaah historis, Imam alHaramain al-Juwaini dapat dikatakan sebagai ahli ushûl pertama yang menekankan pentingnya memahami maqâshid syariah dalam menetapkan hukum Islam. Ia secara tegas mengatakan bahwa seseorang tidak dapat dikatakan mampu menetapkan hukum dalam Islam sebelum ia memahami benar-benar tujuan Allah mengeluarkan perintah-perintah dan larangan-larangan-Nya. Pada prinsipnya AlJuwaini membagi tujuan tasyri' menjadi tiga macam, yaitu dharûriyat, hajiyat, dan mukramat. Pemikiran al-Juwaini tersebut dikembangkan oleh muridnya, al-Ghazâli, yang menjelaskan maksud syari'at dalam kaitannya dengan pembahasan almunasabat al-maslahiyat dalam qiyas. Maslahat menurut al-Ghazâli dicapai dengan cara menjaga lima kebutuhan pokok manusia dalam kehidupannya, yaitu 
memelihara agama, jiwa, akal, keturunan, dan harta. ${ }^{17}$

Pemikir dan ahli teori hukum Islam berikutnya yang secara khusus membahas maqâshid syarî' ah adalah Izzuddin ibn Abd as-Salâm dari mazhab Syâfi'iyah. Ia lebih banyak menekankan dan mengelaborasi konsep maslahat secara hakiki dalam bentuk menolak mafsadat dan menarik manfaat. Menurutnya taklif harus bermuara pada terwujudnya kemaslahatan manusia, baik di dunia maupun di akhirat. Berdasarkan penjelasan ini, dapat dikatakan bahwa Izzuddin ibn Abd as-Salâm telah berusaha mengembangkan konsep maslahat yang merupakan inti pembahasan dari maqâshid syariah. ${ }^{18}$ Pembahasan tentang maqâshid syariah secara khusus, sistematis dan jelas dilakukan oleh As-Shātibi dalam kitabnya al-Muwâfaqât yang sangat terkenal itu. Di situ ia secara tegas mengatakan bahwa tujuan Allah menetapkan hukum-hukum-Nya adalah untuk terwujudnya kemaslahatan hidup manusia, baik di dunia maupun di akhirat. Oleh karena itu, taklif hukum harus mengarah pada realisasi tujuan hukum tersebut.

Wahbah az-Zuhaili dalam bukunya menetapkan syarat-syarat maqâshid syari'ah. Menurutnya bahwa sesuatu baru dapat dikatakan sebagai maqâshid syariah apabila memenuhi empat syarat berikut, ${ }^{19}$ yaitu:

a. Harus bersifat tetap, maksudnya makna-makna yang dimaksudkan itu harus bersifat pasti atau diduga kuat mendekati kepastian.

b. Harus jelas, sehingga para fuqaha tidak akan berbeda dalam penetapan makna tersebut. Sebagai contoh, memelihara keturunan yang merupakan

17 Al-Ghazâli, Al-Mustashfâ min Ilm al-Ushûl, (Beirut: Dâr al-Fikr, tth), 251

18 Amir Mu'alim dan Yusdani, Konfîgurasi Pemikiran Hukum Islam, (Yogyakarta: UII Press, 2001), 51.

${ }^{19}$ Wahbah az-Zuhaili, Ushûl al-Fiqh..., 1019 tujuan disyariatkannya perkawinan.

c. Harus terukur, maksudnya makna itu harus mempunyai ukuran atau batasan yang jelas yang tidak diragukan lagi. Seperti menjaga akal yang merupakan tujuan pengharaman khamr dan ukuran yang ditetapkan adalah kemabukan.

d. Berlaku umum, artinya makna itu tidak akan berbeda karena perbedaan waktu dan tempat. Seperti sifat Islam dan kemampuan untuk memberikan nafkah sebagai persyaratan kafa'ah dalam perkawinan menurut mazhab Maliki.

Lebih lanjut, As-Shātibi dalam uraiannya tentang maqâshid syarî'ah membagi tujuan syariah itu secara umum ke dalam dua kelompok, yaitu tujuan syari'at menurut perumusnya (syari') dan tujuan syari'at menurut pelakunya (mukallaf). Maqâshid syariah dalam konteks maqâshid al-syari' meliputi empat hal, yaitu: ${ }^{20}$

a. Tujuan utama syari'at adalah kemaslahatan manusia di dunia dan di akhirat.

b. Syari'at sebagai sesuatu yang harus dipahami.

c. Syari'at sebagai hukum taklifi yang harus dijalankan.

d. Tujuan syari'at membawa manusia selalu di bawah naungan hukum.

Keempat aspek di atas saling terkait dan berhubungan dengan Allah sebagai pembuat syari'at (syari'). Allah tidak mungkin menetapkan syari'at-Nya kecuali dengan tujuan untuk kemaslahatan hambaNya, baik di dunia maupun di akhirat kelak. Tujuan ini akan terwujud bila ada taklif hukum, dan taklif hukum itu baru dapat dilaksanakan apabila sebelumnya dimengerti dan dipahami oleh manusia. Oleh karena itu semua tujuan akan tercapai

20 Ash-Shâtibi, Al-Muwâfaqât fî Ushûl asySyarî'ah, ..., 70 
bila manusia dalam perilakunya sehari-hari selalu ada di jalur hukum dan tidak berbuat sesuatu menurut hawa nafsunya sendiri.

Maslahat sebagai substansi dari maqâshid syariah dapat dibagi sesuai dengan tinjauannya. Bila dilihat dari aspek pengaruhnya dalam kehidupan manusia, maslahat dapat dibagi menjadi tiga tingkatan:

a. Dharûriyat, yaitu maslahat yang bersifat primer, di mana kehidupan manusia sangat tergantung padanya, baik aspek diniyah (agama) maupun aspek duniawi. Maka ini merupakan sesuatu yang tidak dapat ditinggalkan dalam kehidupan manusia.

Jika itu tidak ada, kehidupan manusia di dunia menjadi hancur dan kehidupan akhirat menjadi rusak (mendapat siksa). Ini merupakan tingkatan maslahat yang paling tinggi. Di dalam Islam, maslahat dharûriyat ini dijaga dari dua sisi: pertama, realisasi dan perwujudannya, dan kedua, memelihara kelestariannya. Contohnya, yang pertama menjaga agama dengan merealisasikan dan melaksanakan segala kewajiban agama, serta yang kedua menjaga kelestarian agama dengan berjuang dan berjihad terhadap musuh-musuh Islam.

b. Hâjiyat, yaitu maslahat yang bersifat sekunder, yang diperlukan oleh manusia untuk mempermudah dalam kehidupan dan menghilangkan kesulitan maupun kesempitan. Jika ia tidak ada, akan terjadi kesulitan dan kesempitan yang implikasinya tidak sampai merusak kehidupan.

c. Tahsiniyat, yaitu maslahat yang merupakan tuntutan muru'ah (moral), dan itu dimaksudkan untuk kebaikan dan kemuliaan. Jika ia tidak ada, maka tidak sampai merusak ataupun menyulitkan kehidupan manusia. Maslahat tahsiniyat ini diperlukan sebagai kebutuhan tersier untuk meningkatkan kualitas kehidupan manusia. $^{21}$

Jenis kedua adalah maslahat yang dilihat dari aspek cakupannya yang dikaitkan dengan komunitas (jama'ah) atau individu (perorangan). Hal ini dibagi dalam dua kategori, yaitu:

a. Maslahat kulliyat, yaitu maslahat yang bersifat universal yang kebaikan dan manfaatnya kembali kepada orang banyak. Contohnya membela negara dari serangan musuh, dan menjaga hadits dari usaha pemalsuan.

b. Maslahat juz'îyat, yaitu maslahat yang bersifat parsial atau individual, seperti pensyari'atan berbagai bentuk mu'amalah.

Jenis ketiga adalah maslahat yang dipandang dari tingkat kekuatan dalil yang mendukungnya. Maslahat dalam hal ini dibagi menjadi tiga, yaitu:

a. Maslahat yang bersifat qath'i yaitu sesuatu yang diyakini membawa kemaslahatan karena didukung oleh dalil-dalil yang tidak mungkin lagi ditakwili, atau yang ditunjuki oleh dalil-dalil yang cukup banyak yang dilakukan lewat penelitian induktif, atau akal secara mudah dapat memahami adanya maslahat itu.

b. Maslahat yang bersifat zhanni, yaitu maslahat yang diputuskan oleh akal, atau maslahat yang ditunjuki oleh dalil zhanni dari syara'.

c. Maslahat yang bersifat wahmiyah, yaitu maslahat atau kebaikan yang dikhayalkan akan bisa dicapai, padahal kalau direnungkan lebih dalam justru yang akan muncul adalah madharat dan mafsadat. ${ }^{22}$

Pembagian maslahat seperti yang dikemukakan oleh Wahbah az-Zuhaili di

\footnotetext{
${ }^{21}$ Az-Zuhaili, Ushûl al-F iqh..., 1020-1023

${ }^{22}$ Az-Zuhaili, Ushûl al-Fiqh..., 1023-1029
} 
atas, agaknya dimaksudkan dalam rangka mempertegas maslahat mana yang boleh diambil dan maslahat mana yang harus diprioritaskan di antara sekian banyak maslahat yang ada. Maslahat dharûriyat harus didahulukan dari maslahat hajiyat, dan maslahat hajiyat harus didahulukan dari maslahat tahsiniyat. Demikian pula maslahat yang bersifat kulliyat harus diprioritaskan dari maslahat yang bersifat juz'iyat. Akhirnya, maslahat qath'iyah harus diutamakan dari maslahat zhanniyah dan wahmiyah. Memperhatikan kandungan dan pembagian maqâshid syariah seperti yang telah dikemukakan di atas, maka dapat dikatakan bahwa maslahat yang merupakan tujuan Tuhan dalam tasyri'-Nya itu mutlak harus diwujudkan karena keselamatan dan kesejahteraan duniawi maupun ukhrawi tidak akan mungkin dicapai tanpa realisasi maslahat itu, terutama maslahat yang bersifat dharûriyat.

Yusuf al-Qardhawi menyebutkan bahwa makna syariat adalah hukum yang ditetapkan oleh Allah bagi hamba-Nya tentang urusan agama, baik berupa ibadah atau muamalah, yang dapat menggerakkan kehidupan manusia. ${ }^{23}$ Sedangkan maksudmaksud syariat adalah tujuan yang menjadi target teks dan hukum-hukum partikular untuk direalisasikan dalam kehidupan manusia, baik berupa perintah, larangan dan mubah, untuk individu, keluarga, jamaah dan umat. ${ }^{24}$ Maksud-maksud tersebut, juga bisa disebut dengan hikmah-hikmah yang menjadi tujuan ditetapkannya hukum. Karena setiap hukum yang disyariatkan Allah untuk hamba-Nya, pasti terdapat hikmah, bisa diketahui oleh orang yang mengetahuinya. Karena Allah Mahasuci untuk membuat syariat yang sewenangwenang, sia-sia, atau kontradiksi dengan sebuah hikmah. ${ }^{25}$

23 Yûsuf al-Qaradhawi, Fîqih Maqâshid asySyarîah, (Jakarta: Pustaka Al-Kautsar, 2007). 12.

${ }^{24}$ Yûsuf al-Qaradhawi, Fîqih Maqâshid asySyarîah ..., 17

${ }^{25}$ Yûsuf al-Qaradhawi, Fîqih Maqâshid asySyarîah ..., 18
Ar-Raisuni mengungkapkan bahwa maqâshid syariah adalah manfaat yang ingin dicapai dalam melakukan sesuatu. Dalam konteks ini maqâshid atau objek yang diletakkan oleh syara dalam mensyariatkan hukum. Istilah populer yang digunakan ialah maqâshid syariah, maqâshid al-Syari' (Allah) dan maqâshid syara'. $^{26}$

Ada yang menganggap maqâshid ialah maslahah itu sendiri, baik mendatangkan maslahah atau menolak mafsadah. Sedangkan Ibn al-Qayyim menegaskan bahwa syariah itu berasaskan kepada hikmah-hikmah dan maslahah-maslahah untuk manusia baik di dunia atau di akhirat. Perubahan hukum yang berlaku berdasarkan perubahan zaman dan tempat adalah untuk menjamin syariat itu dapat mendatangkan kemaslahatan kepada manusia. ${ }^{27}$

Ada juga yang memahami maqâshid sebagai lima prinsip dasar dalam Islam. Asas itu adalah menjaga agama, jiwa, akal, keturunan dan harta. Di satu sudut yang lain, ada juga ulama klasik yang menganggap maqâshid itu sebagai logika pensyariatan sesuatu hukum. ${ }^{28}$ Ibn Ashur mendefinisikan maqâshid sebagai pengertian yang dapat dilihat pada hukumhukum yang disyariatkan pada keseluruhannya atau sebahagian besarnya. ${ }^{29}$

Berbeda dengan Ibnu Ashur, Ahmad Al-Raisuni mendefinisikan maqâshid sebagai sesuatu yang ingin dicapai oleh syariat demi kepentingan umat manusia. Dalam hal ini al-Raisuni membagi maqâshid dengan lebih teliti dalam tiga bagian, yaitu maqâshid umum, maqâshid

${ }^{26}$ Ahmad al-Raisuni, Nazhâriyyat al-Maqâshid inda al-Imâm ash-Shâtibi, (Beirut: al-Mahad alAlâmi li al-Fikr al-Islâmi, 1992), 13

27 Ibn Qayyim al-Jauziyyah, Ilâm alMuwâqqiîn, (Beirut: Dâr al-Kutub al-Ilmiyyah, 1996), Jilid 3, 37

${ }^{28}$ Nuruddin Mukhtar, al-Ijtihad...,50

${ }^{29}$ Mohammad al-Tahir al-Misawi, Ibn Asyur wa Kitâbuhu Maqâshid asy-Syarîah al-Islâmiyyah, (Kuala Lumpur: Al-Basyair li al-Intaj al-Ilmi, 1998), 171 
khusus dan maqâshid parsial (juzî). Menurutnya maqâshid umum ialah objektif yang diambil oleh syara' dalam menentukan semua atau sebahagian besar hukum syara', contohnya konsep keadilan dan kesetaraan (al-Musawah) yang terdapat dalam semua hukum syara'. Maqâshid khusus ialah yang diambil oleh syariah dalam menentukan sesuatu atau beberapa kelompok hukum tertentu, contohnya hukum kekeluargaan. sedangkan maqâshid parsial ialah yang diambil oleh syariah dalam menentukan sesuatu hukum tertentu, contohnya adalah menikah adalah menikah. ${ }^{30}$

Kalau melihat pengertian maqâshid syarîah secara istilah tidak ada definisi khusus yang dibuat oleh para ulama usul fiqh, boleh jadi hal ini sudah dimaklumi dalam kalangan mereka. Termasuk AsShātibi sebagai bapak maqâshid syarîah sendiri tidak membuat tarif yang khusus, beliau cuma mengungkapkan tentang syarîah dan fungsinya bagi manusia seperti yang beliau ungkapannya dalam kitab alMuwâfaqât:

Sesungguhnya syariat itu ditetapkan bertujuan untuk tegaknya (mewujudkan) kemashlahatan manusia di dunia dan akhirat".

Dari ungkapan as-Shâtibi tersebut bisa dikatakan bahwa as-Shâtibi tidak mendefinisikan maqâshid syariah secara konprehensif cuma menegaskan bahwa doktrin maqâshid syarîah adalah satu, yaitu mashlahah atau kebaikan dan kesejahteraan umat manusia baik di dunia maupun di akhirat. Oleh karena itu As-Shātibi meletakkan posisi maslahat sebagai illat hukum atau alasan pensyariatan hukum Islam, ${ }^{31}$ berbeda dengan ahli ushûl fiqih lainnya seperti an-Nabhani misalnya beliau dengan hati-hati menekankan berulangulang, bahwa maslahat itu bukanlah illat atau motif (al-baits) penetapan syariat, melainkan hikmah, hasil (natijah), tujuan

\footnotetext{
${ }^{30}$ Ahmad al-Raisuni, Nazhâriyyat ..., 15.

31 Ash-Shâtibi, Muwâfaqât fî Ushûl asySyarîat, (Kairo: Mustafa Muhammad, t.t), Jilid I, 23
}

(ghayah), atau akibat (aqibah) dari penerapan syariat. $^{32}$

Dari penjelasan diatas memang tidak ada satu ketegasan tentang definisi Maqâshid syarîah dan jika diteliti definisidefinisi yang dikemukakan oleh para ulama tersebut, definisi yang paling tepat, padat dan merangkum seluruh konsep maqâshid ialah definisi yang dikemukakan oleh alRaisuni.

\section{Konsep Maqâshid Syarî'ah dalam Hukum Islam}

Tujuan penetapan hukum atau yang sering dikenal dengan istilah Maqâshid syariah merupakan salah satu konsep penting dalam kajian hukum Islam. Karena begitu pentingnya maqâshid syarî́e ah tersebut, para ahli teori hukum menjadikan maqâshid syariah sebagai sesuatu yang harus dipahami oleh mujtahid yang melakukan ijtihad. Adapun inti dari teori maqâshid syarîee ah adalah untuk mewujudkan kebaikan sekaligus menghindarkan keburukan, atau menarik manfaat dan menolak madharat. Istilah yang sepadan dengan inti dari maqâshid syarî́ah tersebut adalah maslahat, karena penetapan hukum dalam Islam harus bermuara kepada maslahat.

Perlu diketahui bahwa Allah SWT., sebagai syari' (yang menetapkan syari'at) tidak menciptakan hukum dan aturan begitu saja. Akan tetapi hukum dan aturan itu diciptakan dengan tujuan dan maksud tertentu. Ibnu Qayyim al-Jauziyah, sebagaimana dikutip oleh Khairul Umam menyatakan bahwa tujuan syari'at adalah kemaslahatan hamba di dunia dan di akhirat. Syari'at semuanya adil, semuanya berisi rahmat, dan semuanya mengandung hikmah. Setiap masalah yang menyimpang dari keadilan, rahmat, maslahat, dan hikmah pasti bukan ketentuan syari'at. ${ }^{33}$

\footnotetext{
${ }^{32}$ Taqiyuddin an-Nabhani. Asy-Syakhshiyah alIslâmiyya Ushûl al-Fiq (Al-Quds: Min Mansyurat Hizb at-Tahrir. 1953), Juz III, 359-360

${ }^{33}$ Kairul Umam, Ushûl Fîqih, ...127.
} 
Sementara itu, perubahan-perubahan sosial yang dihadapi umat Islam di era modern telah menimbulkan sejumlah masalah serius berkaitan dengan hukum Islam. Di lain pihak, metode yang dikembangkan para pembaru dalam menjawab permasalahan tersebut terlihat belum memuaskan. Dalam penelitian mengenai pembaruan hukum di dunia Islam, disimpulkan bahwa metode yang umumnya dikembangkan oleh pembaru Islam dalam menangani isu-isu hukum masih bertumpu pada pendekatan yang terpilah-pilah dengan mengeksploitasi prinsip takhayyur dan talfî̀ ${ }^{34}$

Maka menjadi kebutuhan yang sangat urgen agar para pembaru Islam saat ini merumuskan suatu metodologi sistematis yang mempunyai akar Islam yang kokoh jika ingin menghasilkan hukum yang komprehensif dan berkembang secara konsisten berdasarkan pertimbangan di atas, maka pengetahuan tentang teori maqâshid syarîah dalam kajian hukum Islam merupakan suatu keniscayaan. Penulis akan mencoba mengemukakan secara sederhana teori maqâshid syarîah tersebut. Poin-poin yang dianggap penting dalam masalah ini meliputi pengertian maqâshid syariah, kandungannya, dan cara mengetahuinya.

Maqâshid syarîah tidak bisa terpisahkan dari ushûl fiqih. Pengembangan yang digunakan dalam metodologi Islam berbeda dengan pengembangan yang digunakan dalam metodologi konvensional. Menurut Firtz Machlup metodologi berarti ilmu tentang prinsip-prinsip yang mengantarkan para pembelajar disiplin ilmu, khususnya beberapa cabang pembelajaran (ilmu) yang lebih tinggi, dalam rangka menentukan proposisi tertentu diterima atau ditolak sebagai bagian dari bagan ilmu yang disusun secara

${ }^{34}$ J.N.D. Anderson, Law Reform in the Muslim World, (London: University of London Press, 1976), 42. umum atau sebagai bagian dari disiplin (ilmu) mereka. ${ }^{35}$

Pengembangan yang digunakan dalam metodologi ekonomi konvensional berdasarkan kepada gejala-gejala ekonomi yang muncul dan bagaimana pengamatan yang telah dilakukan oleh para ahli ekonomi. Metodologi ekonomi konvensional dikembangkan dari interpretasi manusia tentang manusia dan realita kehidupan.

Sedangkan dalam Islam, metodologi dikembangkan dari pemahaman bahwa alam dan isinya adalah ciptaan Allah, maka peraturan-Nyalah yang paling pantas untuk dilaksanakan. Metodologi ilmu ekonomi Islam, dikembangkan dari ajaran-ajaran Islam yang bersumber dari Alquran, Sunnah dan ijtihad. ${ }^{36}$

Sebagai salah satu disiplin ilmu syariah, ushûl fiqh mencakup kajian-kajian tentang sumber-sumber hukum dan metodologi pengembangannya. Akan tetapi, di luar paradigma spesifiknya ini, orang dapat mengatakan bahwa ushûl fiqh memberikan pedoman-pedoman dalam pengkajian dan pemahaman yang benar pada hampir semua cabang kajian Islam, termasuk pada disiplin ilmu ekonomi. ${ }^{37}$

Para ulama bersepakat bahwa fikih itu bermacam-macam jenisnya, seperti fikih ibadah, fikih munākahāt (perkawinan), fikih muāmalah, fikih siyāsah (politik) dan lainnya. Walaupun fikih berhubungan dengan hukum-hukum Islam yang bersifat praktis, tetapi teori-teorinya dapat diterapkan dan dikembangkan dalam masalah ekonomi yang tercakup di bawah fikih muāmalah. Selain itu, para ahli tafsir, fikih dan ilmu kalam juga telah

${ }^{35}$ Masyhudi Muqorobin, "Beberapa Persoalan Metodologis dalam Ilmu Ekonomi: Antara Sekuler dan Islam", dalam Jurnal Ekonomi Sosial Pembangunan, Vol. 2, No. 2, Februai 2018, 1.

36 Muqorobin, Beberapa Persoalan Metodologis dalam Ilmu Ekonomi: Antara Sekuler dan Islam,...11.

37 Muhammad Hashim Kamali. Prinsip dan Teori-Teori Hukum Islam (Ushûl Fîqih), terj. Noorhaidi, (Yogyakarta: Pustaka Pelajar, 1996), v 
menjelaskan nilai-nilai Islam dan penerapannya dalam masalah ekonomi. ${ }^{38}$

Para ekonom muslim beranggapan bahwa nilai-nilai Islam telah mulai mewarnai penerapan ilmu ekonomi di era modern. Akan tetapi, hal ini diperlukan adanya elaborasi metodologi ekonomi yang tepat. Kemudian, metodologi ini dikembangkan dalam ilmu ushûl fiqh lalu dikaitkan dengan ilmu ekonomi konvensional, seperti halnya pada beberapa disiplin ilmu yang lain. ${ }^{39}$

Penerapan ushûl fiqh dalam metodologi ekonomi Islam dapat menggunakan beberapa metode, seperti qiyās (analogi), istihsān (menganggap baik terhadap sesuatu) dan maslahah mursalah atau istislāh (kemaslahatan). Walaupun demikian, antara satu mazhab fikih dengan yang lain terjadi perbedaan pendapat dalam menyikapinya.

Misalnya, seputar qiyās. Qiyās adalah menetapkan hukum suatu kejadian atau peristiwa yang tidak ada dasar nas dengan cara membandingkannya dengan yang telah ditetapkan hukumnya berdasarkan nas karena ada persamaan illat antara kedua peristiwa tersebut. $^{40}$

Mazhab Syāfii menjadikan qiyās sebagai dasar hukum Islam yang keempat. Sedangkan, Muetazilah dan kelompok Zaidiyyah dari aliran Syiah menolak penggunaan qiyās sebagai dasar hukum. Mazhab Hanbali mempunyai pendapat yang lain. Mereka mengatakan bahwa menetapkan hukum berdasarkan hadis mursal itu lebih baik dari pada menggunakan qiyās ${ }^{41}$ Alasan kelompok yang menjadikan qiyās sebagai dasar

\footnotetext{
38 Muqorobin, Beberapa Persoalan Metodologis dalam Ilmu Ekonomi: Antara Sekuler dan Islam.... 15.

39 Muqorobin, Beberapa Persoalan Metodologis dalam Ilmu Ekonomi: Antara Sekuler dan Islam.... 15.

${ }^{40}$ Kamal Mukhtar dkk,. Ushûl Fîqih I dan II. (Yogyakarta: Dana Bhakti Wakaf, 1996), 103, 108, 143.

${ }^{41}$ Muhammad Hashim Kamali. Prinsip dan Teori-Teori Hukum Islam (Ushûl Fîqih)... 280-286.
}

penetapan hukum adalah bahwa salah satu ciri ajaran Islam itu menghilangkan kesukaran (daf" u al-harj). Jika qiyās tidak dianggap sebagai salah satu landasan penetapan hukum, maka hukum Islam akan berlaku dalam wilayah sangat terbatas dan menyebabkan kesulitan bagi pemeluknya.

Qiyās ada dua macam, yaitu qiyās jā $l i$ dan qiyās khafi. ${ }^{42}$ Jika qiyās jāli tidak mampu menyelesaikan permasalah yang ada, maka penyelesaiannya dapat menggunakan qiyās khafi. Tujuannya adalah untuk memberi kemudahan kepada umat Islam dan menegakkan kemaslahatan dan keadilan. Sungguhpun demikian, jika semua metode-metode hukum di atas, belum dapat menyelesaikan permasalahan ekonomi dan keuangan, maka dapat menggunakan metode maslahah mursalah atau istislāh yang populerkan penggunaannya oleh Imam As-Shātibi dari mazhab Maliki. Metode ini juga digunakan oleh sebagian ulama mazhab Syāfieci, seperti Imam al-Tufail, al-Ghazâli dan alĀmidi. Penerapan metode istislāh dalam ekonomi Islam, seperti penerapan teori kepuasan mAsharakat dalam ekonomi konvensional. ${ }^{43}$

Munculnya metodologi dalam ilmu ekonomi konvensional dimulai ketika ilmu ekonomi ini sendiri relatif mapan dan telah mengalami perkembangan yang cukup berarti. Oleh karena itu, keberadaan metodologinya adalah untuk menjustifikasi atau mengabsahkan keberadaan ilmu ekonomi sekaligus dengan praktik-praktik empirisnya.

Situasi yang selalu berubah, menjadi dasar dari pentingnya kemapanan ilmu ekonomi, melalui sebuah metodologi. Tanpa metodologi, konsekuensinya, bila kelak terjadi perubahan mendasar terhadap praktik perekonomian secara global, maka ia juga akan mencari alat justifikasi yang

${ }^{42}$ Kamal Mukhtar dkk,. Ushûl Fîqih I dan II, ... 136-138

43 Muqorobin, Beberapa Persoalan Metodologis dalam Ilmu Ekonomi: Antara Sekuler dan Islam.... 11 
baru dan sesuai, atau sebaliknya mengalami situasi yang tragis dan sulit untuk dibayangkan. ${ }^{44}$

Sedangkan dalam ilmu ekonomi Islam, Islam membangun metodologinya terlebih dahulu. Dalam konteks ini misalnya berbentuk Ushûl fiqh, baru kemudian ilmu fiqh yang tercakup di dalamnya fiqh muāmalat dengan berbagai kategorinya yang berkembang mengikuti metodologi. Dari sini pula suatu sistem kemudian memperoleh berbagai momentum sejarahnya melalui berbagai bentuk, baik teori maupun empiris. Para pemikir Muslim, seperti Ibnu Sina, Ibnu Khaldun, Imam Ghazâli, Imam Abū Hanifah beserta kedua muridnya yaitu Imam Abū Yūsuf dan Imam Syaibani, Imam Malik, Ibnu Taimiyyah dan nama-nama lain yang jumlahnya tidak terhitung telah memformulasikan berbagai perangkat dalam mekanisme ekonomi yang banyak dipakai ilmu ekonomi konvensional saat ini.

Sebagai contoh misalnya Kitāb alKharāj yang ditulis oleh Imam Abu Yusuf. Buku ini disusun atas permintaan Khalifah Harūn al-Rashīd untuk menangani masalah administrasi perpajakan. Dalam Kitab ini, Abū Yūsuf mengemukakan sejumlah maxim atau kaidah dalam perpajakan yang memiliki muatan sama dengan kaidah yang dikembangkan oleh Adam Smith dalam The Wealth of Nation, khususnya "Of Taxes" dalam "The Sources of Revenue" . ${ }^{45}$

Sejarah membuktikan bahwa metode yang dipakai para ulama terdahulu kebanyakan mempergunakan metode penalaran dalam menghadapi suatu kasus yang tidak ditemukan jawabannya dalam Alquran, Sunnah maupun ijmā". Kemudian, mereka menggunakan berbagai bentuk analisa seperti qiyās, istihsān, almasālih al-mursalah dan sebagainya.

44 Muqorobin, Beberapa Persoalan Metodologis dalam Ilmu Ekonomi: Antara Sekuler dan Islam... 270-271

45 Muqorobin, Beberapa Persoalan Metodologis dalam Ilmu Ekonomi: Antara Sekuler dan Islam.... 270-271.
Dengan demikian, mereka senantiasa merujuk pada sumber utama terlebih dahulu jika terdapat permasalahan yang ingin dipecahkan, yaitu Alquran dan al-Sunnah. Kemudian, beralih kepada ijmā atau langsung melakukan ijtihad dengan beberapa pendekatan yang secara garis besar terbagi dua. ${ }^{46}$

Mazhab Shāfii, Mutakallimūn (ahli ilmu kalam) dan kelompok Mutazilah lebih banyak mempergunakan pendekatan teoritis dan filosofis. Dengan pendekatan ini, mereka berharap dapat menjadikannya sebagai standar dalam penyelesaian permasalahan-permasalahan empiris. Metode ini disebut juga Ushûl alSyāfi "iyyah atau tharīqah al-M utakallimūn. Pendekatan ini lebih menekankan eksposisi teori dengan berbagai prinsipnya yang kemudian diformulasikan secara detail ke dalam hukum fiqh. Pendekatan ini tidak terlalu mempedulikan apakah formulasi detail ini akan bersentuhan langsung dengan persoalan praktis ataupun tidak. Untuk yang terakhir ini contohnya adalah berbagai persoalan kenabian.

Sebaliknya, Ushûl al-Hanāfiyyah atau tharīqah al-fuqahā yang dikembangkan oleh mazhab Hanāfi, mempergunakan pendekatan deduktif dengan memformulasikan doktrin teori yang sesuai dengan problem-problem yang relevan dalam masyarakat, sehingga terkesan lebih pragmatik.

Jadi, melalui metodologi yang dikenal dalam Ushûl fiqh inilah kemudian diproduksi hukum-hukum yang memuat semua ketentuan fiqh. Fiqh ini juga diklasifikasikan ke dalam beberapa kategori, salah satunya adalah fiqh muamalah yang memuat ketentuan hukum transaksi perdagangan dan ekonomi. ${ }^{47}$

46 Muqorobin, Beberapa Persoalan Metodologis dalam Ilmu Ekonomi: Antara Sekuler dan Islam.... 272.

47 Muqorobin, Beberapa Persoalan Metodologis dalam Ilmu Ekonomi: Antara Sekuler dan Islam.... 273 
Jika suatu masalah tidak dijumpai jawabannya melalui sumber-sumber hukum diatas, khususnya dalam transaksi perdagangan dan ekonomi, maka para ulama mencari alternatif melalui istislāh. Imam Malik dan kalangan Mazhabnya lebih banyak mempergunakan metode istislāh atau al-masālih al-mursalah. Istislāh merupakan pengambilan hukum yang berdasarkan kepada kepentingan umum (public interest) yang tak terbatas, namun dengan beberapa syarat yang ketat. Ia dibedakan dari yang secara terang diakui oleh syariah atau dikenal al-masālih almutabarah, seperti melindungi kepentingan lima kebutuhan dasar (dharūriyyāt alkhamsah) yaitu: agama, kehidupan, akal, keluarga dan harta benda. Alasan utama pemakaian hukum ini adalah bahwa Allah menurunkan syariat untuk menyediakan kemudahan bagi manusia dalam melaksanakan ajaran-ajaran-Nya. Teori pengambilan hukum ini juga banyak diterima oleh kalangan Shāfiiyyah seperti al-Thūfi, al-Ghazāli dan juga al-Āmidi.

Pembahasan dalam penelitian ini tentunya tidak cukup untuk mengkaji semua persoalan-persoalan dalam Ushûl fiqh. Ada beberapa sumber hukum tambahan di dalamnya yang tidak dapat dibahas dalam penelitian ini. Yang amat penting untuk disampaikan adalah bahwa melalui dua sumber hukum yang terakhir ini, persoalan ekonomi yang dihadapi manusia modern mendapatkan tempat penyelesaian sesuai dengan ketentuan syariah, dengan melalui proses pemikiran dan perenungan berdasarkan syarat-syarat ketat sebagaimana di atas. ${ }^{48}$

Contoh pemakaian metode istihsān dalam ekonomi, Umar dan Usman membentuk partnership atas nama usaha penjualan rumah angsuran, dengan sistem profit and loss sharing (PLS). Ali kemudian membeli rumah tersebut dengan menyerahkan uang muka katakan $\mathrm{Rp}$

48 Muhammad Hashim Kamali. Prinsip dan Teori-Teori Hukum Islam (Ushûl Fîqih)... 321.
10.000.000, yang diterima oleh Umar atas nama mereka berdua.

Tiba-tiba uang tersebut hilang ketika dibawa Umar. Maka berdasarkan ketentuan qiyās jaly, Kerugian atas kehilangan itu ditanggung mereka berdua berdasar sistem PLS. Namun demikian, berdasarkan ketentuan istihsān, hanya Umarlah yang menanggungnya, karena uang tersebut statusnya masih dibawah pengawasan Umar. Sedangkan contoh untuk metode istislāh ini juga banyak ditemukan penerapannya pada para sahabat seperti pengumpulan zakat oleh Khalifah Abu Bakar, salat tarawih dilaksanakan secara berjamaah pada masa Umar, penulisan Alquran pada masa Usman dan lain-lain. ${ }^{49}$

Sampai di sini, barangkali semua kalangan umat Islam masih sepakat. Persoalan selanjutnya muncul, ketika sistem ekonomi yang dominan saat ini berorientasi pada materialisme dan ditopang oleh mapannya landasan teoretik ilmu ekonomi yang kuat. Secara metodologis ada dua isu mendasar yang muncul. Pertama, tentang bagaimana pendefinisikan ilmu (dan sistem) ekonomi Islam, yang kemudian berimplikasi pada munculnya pertanyaan tentang sejak kapan ilmu (dan sistem) ekonomi Islam berlangsung. Pertanyaan ini telah terjawab dengan singkat di bagian atas. Kedua, konsekuensinya, tentang bagaimana menurunkan ketentuan syariah, sehingga menjadi alternatif solusi bagi perkembangan ekonomi modern. Apakah Islamisasi ekonomi merupakan jalan penyelesaian yang tepat. Lalu jika tepat, bagaimana bentuknya. Demikianlah pertanyaan-pertanyaan yang perlu pendalaman lebih lanjut. Ini bukanlah masalah yang sederhana. Diperlukan perhatian dan pembahasan secara lebih luas. Bila proses Islamisasi merujuk pada prosedur di atas, maka Islamisasi adalah sebuah keniscayaan yang tidak dapat dapat ditunda. Namun bila Islamisasi ternyata

\footnotetext{
Muqorobin, Beberapa Persoalan Metodologis dalam Ilmu Ekonomi: Antara Sekuler dan Islam.... 273.
} 
hanya akan lebih menempatkan Islam sebagai alat justifikasi atas praktik-praktik ekonomi yang ada, Allahlah yang akan menjadi saksi, atas hal tersebut. Keduanya memiliki konsekuensi yang amat berbeda dan keduanya juga memiliki kecenderungan bagi keberlangsungannya.

\section{Hubungan antara Maqâshid Syari'ah dengan E konomi Islam.}

\section{Maqâshid Syari'ah sebagai Ushûl-nya Ushûl Ekonomi Islam}

Seperti yang telah dikemukakan sebelumnya bahwa tujuan diturunkannya syariah adalah untuk mencapai kemaslahatan dan menghindari kemafsadatan pada dua dimensi waktu yang berbeda, dunia dan akhirat. Hal ini berarti bahwa semua aspek dalam ajaran Islam, harus mengarah pada tercapainya tujuan tersebut, tidak terkecuali aspek ekonomi. Oleh karenanya Ekonomi Islam harus mampu menjadi pan-acea dan solusi terhadap akutnya problem ekonomi kekinian. Konsekuensi logisnya adalah, bahwa untuk menyusun sebuah bangunan Ekonomi Islam maka tidak bisa dilepaskan dari teori maqâshid seperti yang telah dijelaskan sebelumnya. Bahkan Muhammad Thahir ibn Ashur pernah mengatakan bahwa "melupakan pentingnya sisi maqâshid dalam syariah islam adalah faktor utama penyebab terjadinya stagnasi pada fiqh. ${ }^{50}$

Menghidupkan kembali ekonomi Islam yang telah sekian lama terkubur dan nyaris menjadi sebuah fosil, merupakan lahan ijtihadi. Ini artinya bahwa dituntut kerja keras (ijtihad) dari para ekonom muslim untuk mencari nilai-nilai yang terkandung dalam Alquran dan Sunnah yang terkait dengan ekonomi. Untuk selanjutnya nilainilai ideal tersebut diderivasikan menjadi teori-teori ekonomi yang kemudian dapat dijadikan rumusan/kaidah di dataran

\footnotetext{
${ }^{50}$ Ahmad ar-Raysuni, Nazhâriyat al-Maqâshid ..., 10
}

praksis. Dalam hal ini Syed Nawab Heidar Naqvi menyatakan bahwa kaidah perilaku ekonomi dalam ekonomi Islam tidak dapat dipisahkan dari nilai etik. Selanjutnya ia mengelaborasi lebih jauh peran etika dalam banyak hal, diantaranya etika dan perilaku rasional; etika pada perilaku konsumen; penolakan atas teori Optimum Pareto karena menafikan nilai etik; etika dalam keadilan distributif; dan etika yang dikaitkan dengan peran pemerintah. ${ }^{51}$

Variabel etika, yang dikaitkan dengan maslahah sebagai keyword-nya, tampaknya memang sangat urgen dalam proses ijtihad di wilayah Ekonomi Islam. Sebagaimana yang dinyatakan Said Aqiel Siradj, bahwa dalam mengembangkan metode yang menekankan wawasan etis dengan harapan bisa memenuhi maksud di atas, maslahah sebagai salah satu metode ushûl al-figh selama ini dengan rekonstruksi, perlu dinaikkan derajat dan posisinya menjadi metode sentral ushûl al-fiqh (al-Manhâj alAsasiyyah li Ushûl al-Fiqh). Selain itu fiqh yang lepas dari varibel etika akan menjadi rigid, kaku dan legal-formal. ${ }^{52}$

Selain itu, tawaran tentang Fiqh Maqâshid nampaknya menjadi salah stimulan yang layak dikembangkan oleh para ekonom muslim untuk mengembangkan Ekonomi Islam. Namun perlu ditegaskan terlebih dahulu bahwa apa yang kami maksud dengan figh di sini lebih mengarah pada arti pemahaman, yaitu pemahaman terhadap nilai-nilai yang terkandung dalam aturan syari. Figh alMaqâshid syariah, yaitu sebuah fikih yang dibangun atas dasar tujuan ditetapkannya sebuah hukum. Pada teknisnya, metode ini ditujukan bagaimana memahami nash-nash syari yang juzî dalam konteks maqâshid syarîah dan mengikatkan sebuah hukum dengan tujuan utama ditetapkannya hukum

51 Ulasan selengkapnya tentang hal ini lihat Syed Nawab Haider Naqvi, Islam, Economics and Society, (London \& New York: Kegan Paul International, 1994), 5

${ }^{52}$ Said Aqiel Siradj, Fiqh Berwawasan Etika, dalam www.repulika.co.id, diakses 13 Februari 2018 
tersebut, yaitu melindungi kemaslahatan bagi seluruh manusia, baik dunia maupun akhirat. $^{53}$

Fiqh maqâshid akan mengakhiri babakan sejarah yang selama ini menghadirkan fiqh dalam wajahnya yang kaku, out-of date, sakral, nyaris untouchable dan tidak mempunyai daya sentuh yang maksimal di lapangan. Yusuf al-Qardhawi melihat kenyataan mandulnya fiqh ini ditandai dengan sistematisasi fiqh yang dimulai dengan pembahasan mengenai ibadah. Menurutnya, karakteristik fiqh yang seperti ini telah memandulkan cara pandang fiqh terhadap masalah sosial, politik, dan ekonomi. $^{54}$

Ekonomi Islam yang dalam banyak hal adalah "reinkarnasi" dari fiqh muamalat ${ }^{55}$ sudah semestinya mengembalikan kelenturan dan elastisitas fiqh dengan menjadikan maqâshid syarîah sebagai the ultimate goal dalam proses tersebut. Mengutip pendapat Masdar F. Masudi, bahwa dalam masalah muamalat, irama teks tidak lagi dominan, tetapi yang dominan adalah irama maslahat. Pendapat (al-qawl) yang unggul bukan hanya memiliki dasar teks tapi juga bisa menjamin kemaslahatan dan menghindar dari kerusakan (almafsadah). Oleh karenanya menggunakan kaca mata Fiqh Maqâshid untuk mengoperasionalisasikan nilai-nilai

\footnotetext{
${ }^{53}$ Yûsuf Qardhawi, as-Siyasah asy-Syariyyah fì Dhaui Nushuh asy-Syariah wa Maqâshid iha (Kairo: Maktabah Wahbah, 1998), 228

54 Sebagaimana yang dikutip oleh Zuhairi Misrawi (ed.), Dâri Syariat Menuju Maqâshid Syariat, (Jakarta: KIKJ \& Ford Foundation, 2003), 56. Sebagaimana yang diketahui, Yûsuf al-Qardhawi menulis dua buah buku yang berupaya membedah pembaruan Fiq Sistematika Fiqh tidak dimulai dari peribadatan, akan tetapi dimulai dari permasalahan yang muncul di masyarakat. Dua kitab tersebut adalah Fiqh al-Awlawiyat dan Min Fiqh alMuyassar li al-Muslim al-Muashir.

${ }^{55}$ Untuk diskusi lebih lanjut bahwa Ekonomi Islam adalah Fiqh muamalat, dapat dibaca di A. Qodri Azizy, Membangun Fondasi Ekonomi Umat: Meneropong Prospek Berkembangnya Ekonomi Islam (Yogyakarta: Pustaka Pelajar, 2004), 175199.
}

kemanusiaan universal, seperti kemaslahatan, keadilan dan kesetaraan ke dalam Ekonomi Islam menjadi sebuah keniscayaan. Mengapa ketika mendengar kata "fiqh muamalat" maka kesan yang muncul adalah sesuatu yang usang, kuno dan out-of date, adalah karena selama ini ia lebih dipahami sebagai sebuah hukum (atau bahkan pure fiqh) yang identik dengan stigma-stigma tersebut di atas. Selain itu, pendidikan dan pengajaran di sekolahsekolah (atau bahkan mungkin di level S1 sekalipun) tentang fiqh muamalat tidak lebih dari sekedar aturan normatif, yang "tidak perlu diamalkan; lain halnya dengan fiqh ibadah yang harus diamalkan. Materi dalam pengajaran fiqh mueamalat selama ini hanya sebagai materi di atas kertas, tidak ada kontrol, termasuk kontrol sosial yang dituntut untuk diaplikasikan. ${ }^{56}$

Para ekonom muslim saat melakukan berbagai kajian dan analisis terhadap ekonomi Islam, sebagai salah satu komponen dalam lingkaran Islamic studies, sudah sewajarnya jika melakukan tafsir ulang terhadap nalar syariah yang selama ini berkembang. Dengan menggunakan "packing" yang agak menggelitik, apa yang yang ditawarkan oleh Yudian Wahyudi untuk mensinergiskan antara apa yang ada di Harvard dan apa yang ada dibalik nama besar UIN Sunan Kalijaga dalam bingkai maqâshid syariah, pada proses mengembangkan Ekonomi Islam juga layak untuk diapresiasi. Harvard merupakan salah satu icon pesatnya perkembangan Islamic studies di luar kawasan Timur Tengah; sementara Sunan Kalijaga adalah simbol keberhasilan dakwah/Islamisasi yang mampu mensinergikan antara apa yang tercantum dalam dataran normatif dengan realitas yang terjadi di masyarakat. ${ }^{57} \mathrm{Dus}$, ekonomi Islam semestinya dibangun tanpa 178

56 A. Qodri Azizy, Membangun Fondasi....,

57 Untuk diskusi lebih lanjut baca Yudian Wahyudi, Maqâshid Syarîah dalam Pergumulan Politik; Berfilsafat Hukum Islam Dâri Harvard ke Sunan Kalijaga, (Yogyakarta: Nawesea, 2007). 
menafikan realitas yang ada namun tetap dalam bingkai maqâshid syariah. Ini karena maqâshid syariah sendiri berupaya untuk mengekspresikan penekanan terhadap hubungan antara kandungan kehendak (hukum) Tuhan dengan aspirasi yang manusiawi. ${ }^{58}$ Sampai di sini dapat ditarik sebuah benang merah bahwa teori maqâshid menempati posisi yang sangat sentral dan vital dalam merumuskan metodologi pengembangan ekonomi Islam. Bahkan Shātibi sendiri menyatakan bahwa maqâshid syarîah merupakan UshûlnyaUshûl. $^{59}$

Ini berarti bahwa menyusun Ushûl fiqh sebagai sebagai sebuah metodologi, tidak dapat lepas dari maqâshid syariah. Hal ini karena teori maqâshid dapat mengantarkan para mujtahid untuk menentukan standar kemaslahatan yang sesuai dengan syarîah/hukum. ${ }^{60}$ Bahkan terlebih lagi, menurut at-Tufi, hanya dalam wilayah muamalat sajalah rasionalisasi kemaslahatan ini dapat diterapkan. ${ }^{61}$

58 Wael B. Hallaq, "The Primacy of The Qur"ean in Shātibi Legal Theory", dalam Wael B. Hallaq dan Donald P. Little (eds.), Islâmic Studies Presented to Charles J. Martin (Leiden: EJ. Brill, 1991), 89.

${ }^{59}$ Imâm Shātibi, al-M uwâfaqât...., juz. II, 32. Lebih lanjut ia juga menjelaskan bahwa karena posisinya sebagai ushûlnya ushûl, maka Maqâshid syariah harus berdasar pada dalil-dalil yang qathiy atau defînitif, bukan yang zhonny. Oleh karenanya, menurut Shātibi, dalil naqli yang digunakan sebagai dasar adalah yang mutawatir, sanadnya tersambung dan matan-nya tidak mengandung kecacatan. Selain itu ia juga menolak intervensi nalar/rasio dalam wilayah ini, karena jika digunakan maka nalar/rasio akan dengan mudahnya "menghakimi" agama.

60 Muhammad Khalid Masud, Islâmic Legal Philosophy (Islamabad: Islâmic Research Institute, 1977), 223-224.

61 Yusdani, at-Tufì dan Teorinya tentang Maslahat, dalam www.yusdani.com, diakses 13 Februari 2018. Kami harapkan tidak muncul pemahaman bahwa dalam wilayah ibadah tidak ada maslahah di sana, hanya saja nalar manusia tidak bisa menemukan secara pasti maslahah apa yang ada dibalik penetapan sebuah ibada Maslahah apa yang bisa Anda prediksi Dâri ditetapkannya putaran thawaf harus 7 kali?
Menurut Asafri Jaya Bakri bahwa aspek pertama sebagai aspek inti, karena aspek pertama berkaitan dengan hakikat pemberlakuan syariat oleh Tuhan yaitu kemaslahatan dunia dan akhirat. Hakikat atau tujuan awal pemberlakuan syariat adalah untuk mewujudkan kemaslahatan manusia. ${ }^{62}$ Sebagaimana dikatakan oleh alGhazâli bahwa kemaslahatan itu dapat diwujudkan apabila lima unsur tujuan syarak dapat diwujudkan dan dipelihara yaitu agama, jiwa, akal, keturunan, dan harta. ${ }^{63}$

Dalam usaha untuk mewujudkan dan memelihara lima unsur pokok tersebut, maka as-Shâtibi membagi kepada tiga tingkat maqâshid atau tujuan syarîah, yaitu: ${ }^{64}$

a. Maqâshid ad-Dharûriyat, dimaksudkan untuk memelihara lima unsur pokok dalam kehidupan manusia. $A l$ Dharûriya (tujuan-tujuan primer) ini didefinisikan oleh Yudian Wahyudi $^{65}$ sebagai tujuan yang harus ada, yang ketiadaannya akan berakibat akan menghancurkan kehidupan secara total yang menurut versi yang paling populer adalah melindungi agama, jiwa, akal, harta dan keturunan. Misalnya, untuk menyelamatkan jiwa, Islam mewajibkan umat manusia untuk makan tetapi secara tidak berlebihan. Untuk menyelamatkan harta, Islam mensyariatkan misalnya hukumhukum muamalah sekaligus

62 Asafri Jaya Bakri, Maqâshid Syariah Menurut ash-Shâtibi, (Jakarta: PT Raja Grafîndo Persada, 1996), 71..

${ }^{63}$ Abdul Aziz Dahlan dan dkk, Ensiklopedi Hukum Islam, (Jakarta: PT. Ichtiar Baru van hove, 1996), 1144

64 Asafri Jaya Bakri, Maqâshid Syarîah Menurut ash-Shâtibi..., 72

65 Yudian Wahyudi, Ushûl Fiqh Versus Hermeneutika, (Yogyakarta: Pesantren Nawesea Press, 2006), 45. 
melarang langkah-langkah yang merusaknya seperti pencurian dan perampokan.

b. Maqâshid

al-Hâjiyat,

dimaksudkan untuk menghilangkan kesulitan atau menjadikan pemeliharaan terhadap lima unsur pokok menjadi lebih baik lagi. $A l$ Hâjiyat (tujuan-tujuan sekunder) ini didefinisikan oleh Yudian Wahyudi $^{66}$ sebagai sesuatu yang dibutuhkan oleh manusia untuk mempermudah mencapai kepentingan-kepentingan yang termasuk kedalam katagori dharûriyat, sebaliknya menyingkirkan faktor-faktor yang mempersulit usaha perwujudan dharûriyat. Karena fungsinya yang mendukung dan melengkapi tujuan primer, maka kehadiran sekunder ini dibutuhkan tapi bukan niscaya. Artinya, jika hal-hal hajiyat tidak ada maka kehidupan manusia tidak akan hancur, tetapi akan terjadi berbagai kekurang sempurnaan, bahkan kesulitan. Misalnya, untuk menyelamatkan jiwa sebagai tujuan sekunder melalui makan dibutuhkan peralatan makan seperti kompor. Memang tanpa kompor manusia tidak akan mati karena ia masih bisa menyantap makanan yang tidak di masak, tetapi kehadiran kompor dapat melengkapi jenis menu yang dapat dihidangkan. Terjadi berbagai kemudahan dengan hadirnya kompor. Untuk melindungi harta sebagai tujuan primer maka dibutuhkan peralatan seperti senjata api, memang orang dapat saja melindungi hartanya dengan

66 Yudian Wahyudi, Ushûl Fiqh Versus Hermeneutika..., 45-46. golok, pisau atau sumpit, tetapi senjata api lebih membantu.

c. Maqâshid al-Tahsiniyat, dimaksudkan agar manusia dapat melakukan yang terbaik untuk penyempurnaan pemeliharaan lima unsur pokok. Al-Tahsiniyat (tujuan-tujuan tertier) ini didefinisikan oleh Yudian Wahyudi $^{67}$ sebagai sesuatu yang kehadirannya bukan niscaya maupun dibutuhkan, tetapi akan bersifat akan memperindah poses perwujudan kepentingan dharûriyat dan hâjiyat. Sebaliknya, ketidakhadirannya tidak akan menghancurkan maupun mempersulit kehidupan, tetapi mengurangi rasa keindahan dan etika. Di sini pilihan pribadi sangat dihormati -jadi bersifat ralatif dan lokal- sejauh tidak bertentangan dengan ketentuan nash. Misalnya, kompor yang dibutuhkan dalam dalam rangka mewujudkan tujuan primer yakni menyelamatkan jiwa melalui makan itu bersumbu delapan belas, kompor gas, kompor listrik atau kompor sinar surya diserahkan kepada rasa estetika dan kemampuan lokal. Senjata api yang dibutuhkan dalam rangka merealisir tujuan primer yakni melindungi harta melalui senjata api, itu berlaras panjang atau pendek, buatan Indonesia atau Amerika, berwarna hitam atau putih, dan seterusnya, diserahkan kepada pilihan dan kemampuan lokal.

\section{Islam}

1. Ijtihad dalam Ekonomi

Ijtihad umumnya dikaitkan dalam wilayah hukum, yaitu proses untuk menemukan hukum suatu masalah tertentu dari dalil-dalil yang ada. Namun demikian,

67 Yudian Wahyudi, Ushûl Fiqh Versus Hermeneutika..., 47 
tentulah ijtihad bukan "hak milik" wilayah hukum semata, karena ekonomi Islam pun (apalagi jika ia diidentikkan dengan fiqh muamalat) juga mempunyai "hak" untuk dikembangkan melalui proses ijtihad. Bahkan tidak ada kata final untuk proses ijtihad, karena ekonomi Islam harus elastis sesuai dengan dinamika perputaran roda peradaban yang tak mengenal kata berhenti.Terkait dengan posisi teori maqâshid sebagai pokok pangkal dari proses berijtihad, Shātibi mengintrodusir dua langkah dalam proses ijtihad, yaitu ijtihad istinbathi dan ijtihad tathbiqi. Pembagian yang dilakukan oleh Shātibi ini dapat mempermudah untuk memahami mekanisme ijtihad. Dalam ijtihad istinbathi, seorang ekonom muslim memfokuskan perhatiannya pada upaya penggalian ide yang dikandung dalam teks (al-Quran dan Sunnah) yang masih abstrak. Setelah memperoleh ide-ide tersebut maka kemudian menerapkan ide-ide abstrak tadi pada permasalahan-permasalahan yang terjadi di lapangan; inilah yang disebut dengan ijtihad tathbiqi atau "ijtihad penerapan". Jadi obyek ijtihad istinbathi adalah teks, sedangkan obyek kajian tathbiqi adalah manusia dengan dinamika perubahan dan perkembangan yang dialaminya. Sehingga masuk akal jika kemudian Shātibi menyebut ijtihad tathbiqi sebagai ijtihad yang tidak akan berhenti sampai akhir zaman. ${ }^{68}$

Pembicaraan epistemologi ekonomi Islam mensyaratkan digunakannya metode deduksi dan induksi. Ijtihad tathbiqi yang banyak menggunakan induksi akan menghasilkan kesimpulan yang lebih operasional, sebab ia didasarkan pada kenyataan empiris. Selanjutnya, dari keseluruhan proses ini-yaitu kombinasi dari elaborasi kebenaran wahyu Allah dan asSunnah dengan pemikiran dan penemuan manusia yang dihasilkan dalam ijtihad-

${ }^{68}$ Sebagaimana yang dikutip oleh Asafri Jaya Bakri, Konsep Maqâshid ...., 127-128 akan menghasilkan hukum dalam berbagai bidang kehidupan. ${ }^{69}$

Terkait dengan hal tersebut, maka alkulliyyah al-khamsah sebagaimana yang diintrodusir oleh Shātibi bukanlah sesuatu yang ,eksklusif ${ }^{\text {ee }}$ harga mati yang tidak bisa dikembangkan lebih banyak lagi. Jika para ahli fiqh klasik telah merumuskan pada masa mereka kebutuhan-kebutuhan primer mereka yang dikenal dalam al-kuliyyah alkhamsah, maka kebutuhan manusia tidak cukup hanya lima kebutuhan primer tersebut. Umat Isla, harus mampu menggali dan meletakkan kebutuhan-kebutuhan primer kekinian sebagai maqâshid syarîah, seperti hak kebebasan berpendapat, berpolitik, pemilu dan suksesi, hak mendapat pekerjaan, sandang, pangan dan papan, hak mendapat pendidikan, hak pengobatan dan sebagainya. ${ }^{70}$ Sebagaimana M. Fahim Khan juga menyatakan bahwa:

"Following the lines of Shatibi, the Islamic jurists and economists in the contemporary world are required to work together to determine in detail the determinans of human life. For example, freedom may be the sixth element wich may be required to be promoted along with the promotion of the five elements described by Shatibi.",71

Selanjutnya ia juga menyatakan:

"It may be mentioned that the list of basic elements given by Shatibi may be not an exhaustive list. For example, one element that seems to be missing from the list is freedom. Islam has given great importance to freedom at the individual

${ }^{69}$ Agustianto Mingka, Epistemologi Ekonomi Islam, dalam www.pelita.or.id, diakses tanggal 29 Februari 2018

${ }^{70}$ Muhammad Abid al-Jabiri sebagaimana yang dikutip Muhammad Guntur Romli, Menggagas Figh Maqâshid dalam www.islamlib.com, diakses 29 Oktober 2014.

71 M. Fahim Khan dan Nur Muhammad Ghifari, "Shatibis Objectives of Shariah and Some Implications for Consumer Theory," dalam AbulHasan M. Sadeq dan Aidit Ghazâli (eds.), Reading in Islâmic Economic Thought, (Malaysia: Longman Malaysia, 1992), 194 
level as well as at the society level... Freedom from the dominance of nonmuslim rule is extremly important." 72

Ibnu Ashur juga menyatakan bahwa meskipun al-kuliyyah al-khamsah memang sangat penting, namun secara subtansial sudah tidak memadai untuk mengawal perkembangan dinamika ijtihad kontemporer. Untuk itu, Ashur menawarkan paradigma baru bahwa poros syariat sejatinya terletak pada nilai-nilai universal seperti fitrah, kebebasan (huriyyah), toleran (samahah), egalitarianisme, dan hak asasi manusia. $^{73}$

Seperti yang telah disinggung sebelumnya, bahwa kata kunci dari maqâshid syarîah adalah maslahah. Tawaran yang sangat menghentak dan "kontradiktif" dengan arus main-stream adalah apa yang digagas oleh at-Tufi mengenai teori maslahat. At-Tufi membangun pemikirannya tentang maslahat tersebut berdasarkan atas empat prinsip, yaitu: ${ }^{74}$

a. Akal mempunyai kebebasan menentukan maslahat dan kemafsadatan, khususnya dalam lapangan mueamalah dan adat. Untuk menentukan suatu maslahat atau kemafsadatan dalam wilayah muamalat cukup dengan akal.

b. Sebagai kelanjutan dari poin pertama tersebut, at-Tufi berpendapat bahwa maslahat merupakan dalil syari mandiri yang kehujjahannya tidak

72 M. Fahim Khan dan Nur Muhammad Ghifari, "Shatibis Objectives of Shariah and Some Implications for Consumer Theory," dalam Abul Hasan M. Sadeq dan Aidit Ghazâli (eds.), Reading in Islâmic E conomic Thought,... 195

73 Selengkapnya lihat dalam Muhammad Thahir bin Asyur, Maqâshid ..., 233-312

${ }^{74}$ Untuk bahasan lebih terperinci lihat dalam Mustafa Zaid, Al-Maslahah fî at-Tasyrî al-Islâmi wa Najmuddîn at-Tufì, (Beirut: Dâr al-Fikr, 1954), $127-$ 132 dan Husein Hamid Hasan, Nazhâriah alMaslahah fì al-Fiqh al-Islâmi, (Kairo: Dâr anNahdah al-Arabiyah, 1971), 529 tergantung pada konfirmasi nas, tetapi hanya tergantung pada akal semata. Dengan demikian, maslahat merupakan dalil mandiri dalam menetapkan hukum.

c. Maslahat hanya berlaku dalam lapangan mueamalah dan adat kebiasaan, sedangkan dalam bidang ibadat (mahdah) dan ukuran-ukuran yang ditetapkan syara, tidak termasuk objek maslahat, karena masalahmasalah tersebut merupakan hak Allah semata.

d. Maslahat merupakan dalil syarae paling kuat. Oleh sebab itu, atTufi juga menyatakan apabila nas dan ijma ${ }^{\text {ee }}$ bertentangan dengan maslahat, didahulukan maslahat dengan cara pengkhususan (takhsis) dan perincian (bayan) nas tersebut.

Meskipun tergolong liberal untuk ukuran sezaman at-Tufi, maka idealita dari apa yang disampaikan oleh at-Tufi jika dikaitkan dengan Ekonomi Islam, adalah sudah semestinya Ekonomi Islam akan selalu hidup dan tidak berjalan tertatih di belakang perkembangan peradaban manusia.

Ekonomi Islam akan bersifat elastis, lentur dan dinamis sehingga dapat menjawab setiap persoalan ekonomi umat. Namun demikian elastisitas ini tidak sertamerta diiringi dengan pola pikir yang liberal, yang dapat mencerabut Ekonomi Islam dari akar-akarnya. Sementara itu berbagai macam "versi" maqâshid syarî"ah yang ditawarkan oleh kalangan cendekiawan muslim, merupakan sebuah proses berkesinambungan untuk mencari dan menemukan kehendak Allah SWT.

Meskipun sepintas terlihat ada perbedaan dan pertentangan antar mereka, namun upaya-upaya tersebut semestinya tidak dihadapkan secara diametris dan kontradiktif. Liberalitas at-Tufi tidak perlu dipertentangkan dengan kehati-hatian 
Shātibi yang tetap berpegang pada dalil naqli sebagai Ushûl. Demikian halnya ekstensifikasi al-kuliyyah al-khamsah sebagaimana yang diwacanakan Ibnu "Ashur adalah langkah untuk melengkapi apa yang sudah ada, baik dari sisi metodologis. Selanjutnya, pastilah akan muncul tokoh-tokoh lain dengan tawaran ide yang lebih menggigit yang mungkin saja akan menjadikan pemikiran tokoh sebelumnya terkesan "usang". Pertanyaan kemudian yang mengedepan adalah, siapa dan kriteria bagaimanakah yang mempunyai hak untuk melakukan ijtihad dalam Ekonomi Islam, yang itu merupakan wilayah yang lebih luas dari pada fiqh muamalat? Apakah kriteria seorang mujtahid dalam Ekonomi Islam seketat mujtahid dalam Hukum Islam? Jika memang maqâshid syarîe ah itu adalah Ushûlnya Ushûl, apakah persyaratan bahwa seorang mujtahid dalam Ekonomi Islam itu harus menguasai Bahasa Arab-sebagaimana syarat yang diajukan Shātibi untuk dapat menemukan maqâshid syarî́e ah-berlaku pada setiap orang? Islam tidak menolak pertimbangan bahwa untuk memproduksi barang/jasa harus mempertimbangkan for whom to produce sehingga akan menentukan what to produce. Dengan mengacu pada konsep maslahah sebagi tujuan dari maqâshid syariah, maka proses produksi akan terkait dengan beberapa faktor berikut:

a. Karena produsen dalam Islam tidak hanya mengejar profitability namun juga menjadikan maslahah sebagai barometernya, maka ia tidak akan memproduksi barang/jasa yang tidak searah dengan maqâshid syarî̀ ah, menyalahi al-kulliyyah al-khamsah dan tidak meningkatkan kemaslahatan baik dalam level individu dan sosial. Produsen dalam ekonomi konvensional bisa jadi akan membuka kasino maupun "pasar kembang ala Jogja" demi mengejar keuntungan. Namun tidak demikian halnya dengan produsen dalam Ekonomi Islam, karena kasino bertentangan dengan hifzhil-mâl sedangkan praktik prostitusi tidak sejalan dengan hifzhil-nasl.

b. Dalam banyak hal, jenis dan jumlah supply relatif pada demand. Jika diasumsikan bahwa semua demand di suatu pasar berdasar pada maslahah yang berakar pada needs, maka supply dari produsen akan mengikuti demand tersebut. Pun andaikata masih ada demand yang tidak sesuai kemaslahatan, maka produsen dalam Ekonomi Islam semestinya tidak mensuplai permintaan tersebut hanya karena profit semata. Tentulah apa yang telah diuraikan pada sub-bab ini hanya sebagian kecil dari sekian implikasi maqâshid syariah dalam perilaku ekonomi individu muslim. Selain itu, merupakan sebuah keharusan bahwa yang uraian tentang implikasi di atas merupakan bentuk dari ijtihad individual yang perlu dikomunikasikan dengan para mujtahid lainnya.

Ilmu ushûl fiqh sangat langka diajarkan pada Lembaga Keuangan Syariah, bahkan materi bahasannya tidak ditemukan sama sekali. Oleh karena itu para pakar ekonomi Islam dan SDM bank syariah termasuk regulator syariah sangat jarang memahami ilmu ushûl fiqh.

Cukup penting adalah tentang akad ta'alluq. Ada banyak pandangan yang mengenerasisasi semua ta"alluq itu dilarang, semua jual beli bersyarat itu dilarang, tanpa mengkaji dan memahami mengapa ta'alluq itu dilarang, apa illatnya, bentuk ta'alluq yang bagaimana yang dilarang dan bentuk ta'alluq bagaimana yang dibolehkan?. Mengapa jual beli bersyarat itu dilarang, apa illatnya? Semua 
pengetahuan ini sangat berguna menghasilkan pengetahuan-pengetahuan baru yaitu akan memberikan pemahaman apa dan bagaimana bentuk akad ta'alluq yang dilarang dan mana pula yang dibolehkan, begitu pula jual beli bersyarat, mana jual beli yang dilarang dan mana pula yang dibolehkan.Semua analisisnya harus didasarkan pada kajian illat dalam metodologi ushûl fiqh.

Contoh lainnya yang juga menarik adalah akad sewa beli (lease and purchase), apakah akad ini bisa disebut sebagai gharar? Apa yg gharar dalam akad ini?. Ketidakjelasan akadnya sewa atau beli, atau dianggap tidak jelas pemindahahan kepemilikan? Di sinilah diperlukan kajian illat dan maqâshid syarîe ah, sebuah kajian falsafah syariah mengapa gharar itu dilarang, apakah illatnya terdapat pada akad sewa beli itu? Secara praktis, sebenarnya akad sewa beli tidak gharar, karena akadnya sudah jelas sekali. Begitu sewa berakhir,maka secara otomatis dan demi hukum asset menjadi milik nasabah, tanpa perlu akad baru lagi, karena janji hibah yang diaktekan ada saat akad sudah terwujud secara otomatis setelah berakhirnya periode sewa. Kejelasan akad sewa beli ini, tidak akan memancing dispute atau rawan perselisihan, karena itu hukumnya boleh. Jual beli gharar yang illatnya sudah hilang, hukumnya boleh, sesuai dengan kaedah al hukm yaduru ma'a al- illat wujudan wa adaman.

Dalam kasus ini gharar itu dilarang karena akan sangat rawan menimbulkan perselisihan para pihak, sedangkan dalam akad sewa beli semuanya sudah jelas, sama jelasnya dengan kontrak jual beli. Karena akad yang jelas itu maka peluang perselisihan akibat akad hybrid sebenarnya tidak ada. Kalaupun peluang dispute ada, tapi porsinya sedikit sekali dan kecil sekali, bahkan disputenya bukan karena ghararnya, melainkan karena moral hazard di antara kedua pihak, misalnya dengan sengaja menunda pembayaran cicilan. Kecilnya peluang perselisihan sewa sama saja dengan kecilnya peluang jual beli murabah cicilan, sebab setiap akad pasti selalu ada kemungkinan terjadinya perselisihan, tapi sekali lagi bukan karena ketidakjelasan akadnya, melainkan karena Morald Hazard terutama dari nasabah yang mencicil. Bila digunakan logika yang jernih, kalau ada akad lease and purchase tanpa hunga, dengan ketentuan akad yang jelas, maka hukumnya boleh, karena tidak gharar. Dengan demikian tidak semua gharar yang dilarang. Hanya gharar yang besar saja yang dilarang, yaitu yang peluang mendatangkan perselisihan saja yg dilarang syariah, sedangkan gharar yang sedikit tidak dilarang. Oleh karena itulah ulama membagi gharar kepada 3 macam, gharar katsir, gharar mutawassith dan gharar qalil.

Kemahiran menemukan illat, maslalah dan maqasahid dari suatu akad dan transaksi sangat diperlukan, mengingat kasus-kasus baru terus bermunculan, seperti pembiayaan KPR syariah secara indent, MDC (Margin During Construction), tawarruq munazzam, dsb. Ilmu ushûl fiqh akan merekonstruksi illat dari larangan jual beli indent (KPR (Property Syariah)), bentuk pembiayaan KPR indent bagaimana yang dilarang? Mengapa dalam jual beli salam, uangnya harus cash? sehingga jual beli kali bikali (al-bay" bi ajli badalain) dilarang?, dan Bentuk kali bi kali bagaimana yang dilarang, dan mengapa dilarang? Apa perbedaan illat antara KPRS Indent (yang menggunakan akad MMQ) dengan jual beli kali bi kali yang dilarang Nabi Muhammad saw?. Atau dengan perkataan lain, apakah boleh cicilan pada salam fil manafi" untuk pembiayaan KPRS Indent dengan musyarakah mutanaqishah? Kalau dilarang apa illatnya? Apakah illatnya sudah berubah dan berbeda dengan illat kali bi kali?. Kalau illatnya sama maka KPRS indent dengan MMQ tentu tidak dibolehkan, tetapi jika illatnya berbeda, maka KPRS Indent dengan MMQ dibolehkan. Disinilah diperlukan kecerdasan dan kepiawaian dalam 
menemukan illat suatu kasus keuangan syariah.

Upaya menemukan illat sering kali membutuhkan pengetahuan disiplin ilmu lain yang terkait, misalnya ilmu ekonomi makro. Mungkin secara figh muamalah formal, suatu kasus dibolehkan, tetapi setelah mengkaji maslahat dan mudharatnya dari perspektif ilmu ekonomi makro, sesuatu kasus situ bisa dilarang. Karena itu jangan terjebak kepada kerangkeng fiqh muamalah, tapi temukanlah illat, temukan maslahah dan mudharat dalam sinaran maqâshid syariah. Mungkin saja seseorang ahli dalam Ushûl fiqh, tapi tidak menggunakan pisau analisis ilmu ekonomi makro, sehingga tidak bisa menemukan illat dengan tepat di bidang ekonomi. Misalnya ada seorang pakar di luar negeri yang membolehkan transaksi bursa komodity berjangka karena mengqiyaskannya dengan bay salam, secara formal memang kelihatannya mirip. Namun secara illat dan maqâshid, terdapat unsur derivatif ribawi di dalamnya, sehingga transkasi itu menjadi terlarang.

Contoh lain yang cukup sederhana antara lain tentang illat larangan riba, dikatakan illatnya zhulm. Kesalahan menemukan illat riba, akan menimbulkan kesalahan fatal berikutnya, misalnya menganggap suku bunga bank di Jepang yang berkisar 2-3 persen setahun adalah tidak riba dibanding margin murabahah di Indonesia yang mencapai 10-12 persen setahun. Di sini dibutuhkan teori-teori ilmu ekonomi makro Islami, seperti teori inflasi, teori bubble dan krisis, hubungannya dengan produksi, employment, dan sebagainya. Pakar ekonomi Islam dan hukum ekonomi Islam harus bisa menemukan illatnya secara tepat dan akurat. Pengetahuan tentang illat ini begitu urgen, karena dengan mengetahui illat, maka ketentuan fikih muamalah akan selalu bermuatan maslahah dan maqâshid syariah sehingga syariah akan selalu aktual, segar dan relevan dengan perubahan-perubahan bisnis dan tuntutan-kemajuan-zaman.
Dalam ilmu Ushûl fiqh kajian tentang illat dibahas dalam sub bahasan masâlikul illat, yang dimulai dari takhrîjul manath, kemudian tanqihul manath dan terakhir tahqiqul manath. Selanjutnya dalam kajian illat dan maslahah, seorang ahli Ushûl fiqh harus bisa menentukan qiyas jaliy dan qiyas khafi dalam banyak kasus ekonomi keuangan, tanpa pengetahuan tentang qiyas jaliy dan qiyas khafiy, maka akan mengakibatkan pandangan yang keliru dalam memahami suatu konsep fiqh muamalah, seperti menggenerasilasi semua tawarruq dilarang. Padahal harus dibedakan tawarruq munazzam pada umumnya dengan tawarruq yang nyata-nyata sektor riil, untuk pembiayaan pertaniandan UMKM, maka penyalurannya juga pasti menganalisa risiko dan kalkulasi bisnis pertanian itu. Dengan demikian, pakar keuangan syariah, akademisi dan praktisi harus bisa memahami konsep istihsan dengan baik, agar pemahaman keuangan syariahnya utuh dan komprehensif. ${ }^{75}$

\section{Kesimpulan}

Maqashid syariah adalah tujuantujuan syariat dan rahasia-rahasia yang dimaksudkan oleh allah dalam setiap hukum dari keseluruan hukumnya. Inti dari tujuan syariah adalah merealisasikan kemaslahatan bagi manusia dan menghilangkan kemudorotan, sedangkan mabadi (pokok dasar) yakni memperhatikan nilai-nilai dasar Islam. Seperti keadilan persamaan, dan kemerdekaan. Ilmu ushûl fiqh yang bermuatan maqâshid syariah akan memberikan pemikiran rasional dan filosofis tentang ketentuan ketentuan fiqh muamalah dan fatwa-fatwa, yang berkaitan dengan perkembangan ekonomi Islam.

\section{DAFTAR PUSTAKA}

Abid al-Jabiri, Muhammad sebagaimana yang dikutip Muhammad Guntur Romli, Menggagas Fiqh Maqâshid

75 Agustianto Mingka, Epistemologi Ekonomi Islam, dalam agustiantocenter.com, diakses tanggal 29 Pebruari 2018 
dalam www.islamlib.com, diakses 29 Oktober 2014.

Al-Ghazâli, Al-Mustashfâ min Ilm alUshûl, Beirut: Dâr al-Fikr, tth

Al-Izz bin Abdul as-Salâm, Qawâid alAhkâm fî Mashâlihi al-Anâm, Beirut: Dâr al-Kutub al-Ilmiyyah, 2001

Allal Al-Fasy, Maqâshid asy-Syarî'ah alIslâmiyyah wa Makârimuha, KSA: Dârul Garb Al-Islamy. 1993

al-Qaradhawi, Yûsuf, Fîqih Maqâshid asy-Syarîah, Jakarta: Pustaka AlKautsar, 2007

al-Raisuni, Ahmad, Nazhâriyyat alMaqâshid inda al-Imâm ash-Shâtibi, Beirut: al-Mahad al-Alâmi li al-Fikr al-Islâmi, 1992

al-Tahir al-Misawi, Mohammad, Ibn Asyur wa Kitâbuhu Maqâshid asySyarîah al-Islâmiyyah, Kuala Lumpur: Al-Basyair li al-Intaj al-Ilmi, 1998

al-Wahab Khallaf, Abd, Ilmu Ushûl alFiqh, Kairo: Maktabah al-Da'wah alIslâmiyah, 1968

Amir Mu'alim dan Yusdani, Konfìgurasi Pemikiran Hukum Islam, Yogyakarta: UII Press, 2001

Anderson, J.N.D. Law Reform in the Muslim World, London: University of London Press, 1976

an-Nabhani. Taqiyuddin, Asy-Syakhshiyah al-Islâmiyyah. Ushûl al-Fiqh. AlQuds: Min Mansyurat Hizb at-Tahrir. 1953

Aqiel Siradj, Said, Fiqh Berwawasan Etika, dalam www.repulika.co.id, diakses 13 Februari 2018

ar-Raisuni, Ahmad, Nazhâriyyat alMaqâshid inda al-Imâm ash-Shâtibi, Beirut: al-Maahad al-Alami li al-Fikr al-Islâmi, 1992

Asafri Jaya Bakri, Maqâshid Syariah Menurut ash-Shâtibi, Jakarta: PT Raja Grafîndo Persada, 1996

Ash-Shâtibi, Al-Muwâfaqât fî̀ Ushûl asySyarî'ah, Riyadh: Maktabah alRiyadh al-Haditsah, tth
Ash-Shâtibi, Muwâfaqât fî̀ Ushûl asySyarîat, Kairo: Mustafa Muhammad, t.th.

Aziz Dahlan, Abdul dkk, Ensiklopedi Hukum Islam, Jakarta: PT. Ichtiar Baru Van Hove, 1996

Azizy, A. Qodri, Membangun Fondasi Ekonomi Umat: Meneropong Prospek Berkembangnya Ekonomi Islam, Yogyakarta: Pustaka Pelajar, 2004

az-Zuhaili, Wahbah, Ushûl al-Fiqh alIslâmi, Beirut: Dâr al-Fikr, 1986

Fazlur Rahman, Islam, alih bahasa: Ahsin Muhammad, Bandung: Pustaka, 1994

Hallaq, Wael B. "The Primacy of The Quran in Shātibi Legal Theory", dalam Wael B. Hallaq dan Donald P. Little (eds.), Islâmic Studies Presented to Charles J. Martin Leiden: EJ. Brill, 1991

Hashim Kamali. Muhammad, Prinsip dan Teori-Teori Hukum Islam (Ushûl Fîqih), terj. Noorhaidi, Yogyakarta: Pustaka Pelajar, 1996

Husein Hamid Hasan, Nazhâriah alMaslahah fî al-Fiqh al-Islâmi, Kairo: Dâr an-Nahdah al-Arabiyah, 1971

Ibn Qayyim al-Jauziyyah, Ilâm alMuwâqqiîn, Beirut: Dâr al-Kutub alIlmiyyah, 1996

Ibnu Mansur al-Afriqi, Lisan al-Arab, Beirut: Dâr al-Sadr, t.th

M. Fahim Khan dan Nur Muhammad Ghifari, "Shatibis Objectives of Shariah and Some Implications for Consumer Theory," dalam AbulHasan M. Sadeq dan Aidit Ghazâli (eds.), Reading in Islâmic Economic Thought, Malaysia: Longman Malaysia, 1992

Mingka, Agustianto, Epistemologi Ekonomi Islam, dalam agustiantocenter.com, diakses tanggal 29 Pebruari 2018

Misrawi (ed.), Zuhairi, Dâri Syariat Menuju Maqâshid Syariat, Jakarta: KIKJ \& Ford Foundation, 2003 
Muhammad Khalid Masud, Islâmic Legal Philosophy, Islamabad: Islâmic Research Institute, 1977

Mukhtar dkk, Kamal, Ushûl Fîqih I dan II. Yogyakarta: Dana Bhakti Wakaf, 1996

Mukhtar, Nuruddin, al-Ijtihad alMaqâshidi, Qatar: Dâr al-Muassasah, 1998

Muqorobin, Masyhudi, "Beberapa Persoalan Metodologis dalam Ilmu Ekonomi: Antara Sekuler dan Islam, dalam Jurnal Ekonomi Sosial Pembangunan, Vol. 2, No. 2, Februai 2018

Nawab Haider Naqvi, Syed, Islam, Economics and Society, London \& New York: Kegan Paul International, 1994

Qardhawi, Yûsuf, as-Siyasah asySyariyyah fi Dhaui Nushuh asySyariah wa Maqâshid iha, Kairo: Maktabah Wahbah, 1998

Saad al-Yubi, Muhammad, Maqâshid asySyarî'ah al-Islâmiyah wa Alaqâtuha bi al-Adillah asy-Syar' îyyah, KSA: Dâr al-Hijrah li an-Nasyr wa at-Tauzi, 1998

Syaltout, Mahmud, Islâm: Aqîdah wa Syarîah, Kairo: Dâr al-Qalam, 1966

Umam, Khairul, Ushûl Fîqih, Bandung: Pustaka Setia, 2001

Wahyudi, Yudian, Maqâshid Syarîah dalam Pergumulan Politik; Berfilsafat Hukum Islam Dâri Harvard ke Sunan Kalijaga, Yogyakarta: Nawesea, 2007

Wahyudi, Yudian, Ushûl Fiqh Versus Hermeneutika, Yogyakarta: Pesantren Nawesea Press, 2006

Zaid, Mustafa, Al-Maslahah fì at-Tasyrî al-Islâmi wa Najmuddîn at-Tufî, Beirut: Dâr al-Fikr, 1954 